\title{
OCCURRENCE PATTERN ANALYSIS OF DRAGONFLIES (ODONATA) ON THE RIVER TISZA BETWEEN VILOK AND HUSZT BASED ON EXUVIAE
}

\author{
KOLOZSVÁRI, I. ${ }^{1,2 *}-$ SZABÓ, L.J. ${ }^{1}-$ DÉVAI, GY. ${ }^{1}$ \\ ${ }^{I}$ Department of Hydrobiology, University of Debrecen, Egyetem tér 1, H-4032 Debrecen, \\ Hungary \\ ${ }^{2}$ Ferenc Rákóczi II. Transcarpathian Hungarian Institute, István Fodor Research Institute, \\ Kossuth Square 6, UA-90202 Beregove, Ukraine \\ (phone: +36 (52) 512-900/22621; fax: +36 (52) 431-148) \\ *Corresponding author \\ e-mail:kolozsvaros@gmail.com \\ (Received $12^{\text {th }}$ Jul 2014; accepted $2^{\text {nd }}$ Nov 2015)
}

\begin{abstract}
Dragonfly exuviae were collected between 2010 and 2013 in the following sections of River Tisza: Vilok (Вилок, Tiszaújlak), Nove Szelo (Нове Село, Tiszaújhely), Tiszobikeny (Тисабікень, Tiszabökény), Vinohragyiv (Виноградів, Nagyszölős) and Huszt (Хуст, Huszt). Based on the examination of the 1965 exuviae, collected from 13 main channel sections, 6 dragonfly species were identified [Gomphus vulgatissimus (Linnaeus, 1758), Gomphus flavipes (Charpentier, 1825), Onychogomphus forcipatus (Linnaeus, 1758), Ophiogomphus cecilia (Fourcroy, 1785), Calopteryx splendens (Harris, 1782), Platycnemis pennipes (Pallas, 1771)]. Summing up the collected exuviae, the two most frequent species were G. vulgatissimus (57.3\%) and $O$. forcipatus (39.08\%), however significant assemblages of $O$. cecilia $(1.93 \%)$, G. flavipes $(1.17 \%)$, C. splendens $(0.36 \%)$ and P. pennipes $(0.15 \%)$ could be found as well. In compliance with the Mantel test the channel and riverbank characteristics show a significant correlation with the composition of dragonfly assemblages $(R=0.309$, $\mathrm{p}=0$ 024). According to the canonical correspondence analysis ( 15 habitat characteristics) the exuviae data of $G$. vulgatissimus are connected with the extent of plant coverage, the closure of foliage and the characteristics of riverbanks; the exuviae data of $O$. forcipatus are associated with water depth, channel deepening tendency, water temperature and type of plant coverage on the river bank.
\end{abstract}

Keywords: Upper-Tisza, Ukraine, Odonata, Gomphidae, exuviae

\section{Introduction}

Little is known about the structure of dragonfly assemblages in the Ukrainian section of River Tisza. The earliest published data concerning dragonflies in Transcarpathia (Zakarpatska region) are from the second half of the $19^{\text {th }}$ century by Kohaut (1896). At the beginning of the $20^{\text {th }}$ century their work was continued by Hrabár (1905). Besides, interesting observations were carried out also by Fudakowski (1935) in the area of Chornohora massif, as well as the results of the Transcarpathian data publishing by Павлюк (1990), Mauersberger (1994), Добей and Бондарчук (1998), Vizslán and Huber (2001), Рязанова (2007), Holuša (2009), Martynov and Martynov (2010). Unfortunately, the published sampling sites concerning River Tisza are quite insufficient and they are often difficult to find. Further problematic issue is that a significant portion of the published data is about the results of imago observations. Imago data is not appropriate for a reliable description of an aquatic habitat as dragonfly imagos usually fly kilometres away from their place of emergence. 
Partial information can be obtained about the dragonfly species of the Ukrainian Tisza section from Павлюк's (1990) imago observations on the dead channel of Tisza at Huszt; from the results of the occasional sampling of macroinvertebrate monitoring by Kovács et al. (Kovács and Godunko, 2008; Kovács et al., 2008), and from Kolozsvári and Illár (2009), as well as from Kolozsvári and Dévai (2013) from the earlier investigations on River Tisza between Vilok and Huszt.

Dragonflies are excellent indicator organisms (Schindler et al., 2003). The River Tisza section that we examined, has still preserved its natural anastomosing characteristics in many ways. From the point of biodiversity research the significance of the so naturally preserved habitats is increasing (Noss, 1990; Ward et al., 1999; Amoros, 2001). The particular ecological relationships are threatened by the strengthening civilizational interventions, so exploring the natural value of the upper parts of the River Tisza needs priority. Earlier investigations have proved that dragonflies are quite sensitive to those changes that affect their habitats. The composition of riverine dragonfly assemblages may be influenced by the riverbed conditions, the stream characteristics, the plant coverage and the river bank transformation (Chovanec and Waringer, 2001; Schindler et al., 2003). In our work we set the aim to make a survey on the composition of dragonfly species on the main channel of River Tisza between Vilok and Huszt. While collecting exuviae it was often experienced that the place of emergence was preferred to a different degree in the river sections and on the different parts of the river bank by the dragonflies (Brookes, 1994; Beisel, et al., 1998; Brunke et. al., 2001; D’Amico et al., 2004; Hardersen, 2008; Raebel et al., 2010; Bereczki et. al., 2012 Giugliano et al., 2012). The terrain objects in the riverbed and on the river banks, the driftwood, the plants, etc., all affect the stream, the alluvium transportation, the erosion, and riverbed depth (Montgomery and Buffington, 1997; Robert 2011; Ward et al., 2002). These previously mentioned factors influence the abundance and density of dragonflies (Petts, 1984 cit. Brookes, 1994). Unfortunately, the habitat factors and their connections in the background of the phenomenon are not exactly known therefore while collecting exuviae, relations between dragonfly assemblages, river banks, and channel characteristics were examined. Water quality degradation and immoderate fluctuation of water regime throughout Europe are serious dangers to the survival of riverine dragonflies, therefore the exploration and protection of their natural habitat is of great importance (Jakab and Dévai, 2008).

\section{Materials and methods}

Between 2011 and 2013 exuviae were collected in the section between Vilok (Вилок, Tiszaújlak) and Huszt (Хуст, Huszt) from the River Tisza. Collections were carried out along $30 \mathrm{~m}$ long stretches that were marked out at Vilok (Вилок, Tiszaújlak), Nove Szelo (Нове Село, Tiszaújhely), Tiszobikeny (Тисабікень, Tiszabökény), Vinohragyiv (Виноградів, Nagyszőlős) and Huszt (Хуст, Huszt) on the main channel of River Tisza (Fig. 1).

Typical river banks in this section were point bars [F1TL (Vilok), F2TL (Vilok), F4TL (Vilok), F1TB (Tiszobikeny), F1NSZ (Vinohragyiv), F1H (Huszt)]; cut banks [F1TH (Nove Szelo), F2TH (Nove Szelo), F3H (Huszt)] and artificially reconstructed protected banks [F3TL (Vilok), F2TB (Tiszobikeny), F2NSZ (Vinohragyiv), F2H (Huszt)]. Our sampling sites were divided into two main 
groups based on the features of the terrain. The sites at Vilok, Nove Szelo and Tiszobikeny were mainly flat while at Vinohragyiv and Huszt they were at the foot of the mountain (Fig. 1). The transliteration of settlement names follows the form suggested by Molnár and Molnár (2005).

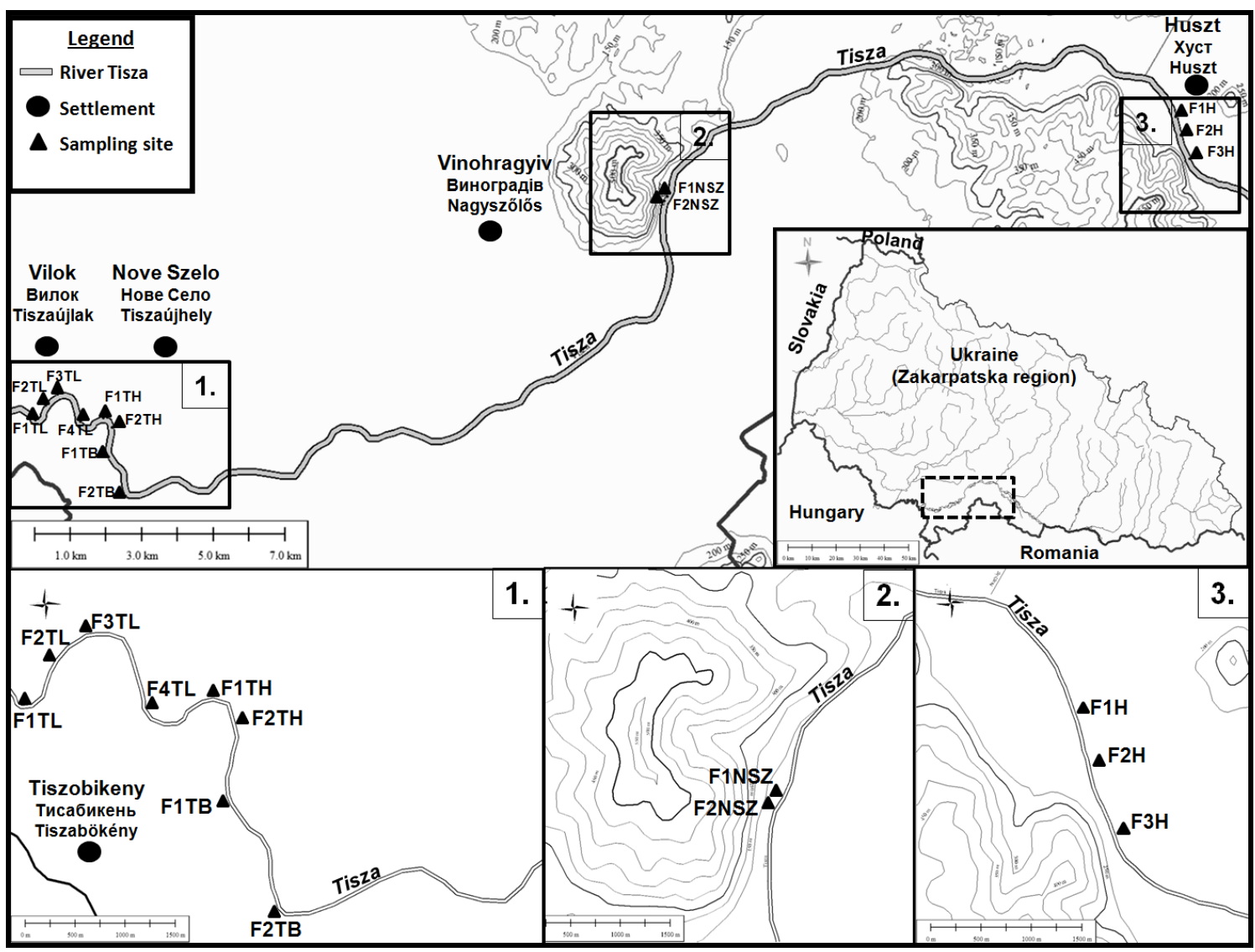

Figure 1. The examined section of River Tisza between Vilok and Huszt

In the examined section of River Tisza heavy rains are followed by quick water level fluctuations (Gönczy and Molnár, 2004). Regularly occurring spates contribute to alluvium movement, bow deepening, alluvial filling of other channel parts, and river bank change (Németh, 1954; Brookes, 1994; Church, 1994; Robert, 2003; Richard et al., 2005; Hoffmann and Gabet, 2007).

When the sampling sites were marked out the main aim was to most completely cover and examine the typical characteristics of the variegated bank and channel structures of the dragonfly habitats. The collection of exuviae can be hindered by the quick rise of water level causing their removal from the river bank (Farkas et. al., 2011, 2012). Exuviae were collected with hand-picking method from riverbanks and plants on the channel and banks. Our collections in the years of investigation were carried out from May to July. Because of the great distances between the sampling sites, samplings were done on every fourth day on the same sampling site.

Some exuviae were presumably washed away on days when water level rose significantly. The identification of the cast off cases (exoskeleton) was based on the works of Askew (2004), Bellmann (2007), Gerken and Sternberg (1999). 
It was confirmed earlier that the composition of aquatic macroinvertebrate assemblages is influenced by biotic and abiotic factors of the channel, thus water flow speed, composition of the channel bottom and river bank, plant coverage rate and its characteristics (Corbet, 1983; Gibbons and Pain, 1992; Brookes, 1994; Beisel et al., 1998; Brunke et al., 2001; Müller, 2002; Angelier, 2003; Ward and Mill, 2005; Bereczki et al., 2012). Examining the river bank and channel characteristics of the sampling sites the following factors were taken into consideration: channel width (1), water depth in the stream-channel (2), deepening tendency of the channel (3), mosaiclike nature of the channel (4), condition of the channel near the river banks (5), type of plant coverage on the river bank (6), rate of plant coverage of the riverbank (7), rate of foliage closure (8), intensity of water flow near the river banks (9), water colour (10), water temperature (11), type of the river bank (12), in case of river bank protection, characteristics of the work (13), characteristics of the river bank (14), and forms of the river banks (15).

Before data processing Mardia's test was used to test multiple normality of the abundance data. The composition of dragonfly assemblages was compared with cluster analysis (Ward's method), principal component analysis (Bray-Curtis similarity) and canonical variate analysis (CVA). The SIMPER method was applied to demonstrate which species resulted the differences among groups of assemblages. The relationship between 15 river characteristics and the examined species was analysed with Mantel test and canonical correspondence analysis (CCA). For statistical analyses PAST program package was used (Hammer, Harper and Ryan, 2001).

The cartographic representation of the sampling sites was carried out using the Environmental Systems Research Institute (ESRI) ArcGIS 10.0 - ArcMap geoinformatics software.

\section{Results and Evaluation}

During the study a total of 1965 exuviae were collected from 13 sampling sites on the main channel of River Tisza between Vilok and Huszt. Based on the examination of the main channel 6 dragonfly species were identified [Gomphus vulgatissimus (Linnaeus, 1758), Gomphus flavipes (Charpentier, 1825), Onychogomphus forcipatus (Linnaeus, 1758), Ophiogomphus cecilia (Fourcroy, 1785), Calopteryx splendens (Harris, 1782) and Platycnemis pennipes (Pallas, 1771)]. There were great differences in the species composition of the habitats and in the qualitative abundance of the species.

In the area of Vilok 681 exuviae were collected from four main channel sampling sites. The given section of the river shows great variety and dynamically changing bank structure and channel material. From ecological viewpoint, river banks play an important role in habitat characterization, because they mean transition between aquatic and terrestrial habitats (Bravard et al., 1986; Large and Petts, 1994) that is of vital concernment for amphibian insects. The affect of the water stream on the river bank alteration, among natural circumstances, firstly depends on the water speed, the direction and degree of the turbulent water streams appearing on the given river section, as well as on the river bed and river bank material resistance characteristics (Lászlóffy, 1949; Brookes, 1994; Carling, 1994; Robert, 2003). These conditions can be deeply affected by river bank protection and regulation works. These interventions influence the life opportunities of macroinvertebrates in a still partially unknown way. The linkage of dragonfly larvae to the certain types and compositions of riverbed material 
has not been completely revealed yet. In many cases river bed material preference differences can be observed among the larvae of the same species (Suhling, 1996). On the F1TL, F2TL and F4TL stretches the channel is gradually deepening with point bars. Differences could be found in the bank and channel material. The F2TL stretch is uniformly pebbled, the F4TL stretch is pebbled and sandy-soiled, while the F1TL site bears a completely sandy and muddy character. The bank of the F3TL stretch is steep; the bottom is abruptly deepening with earlier signs of river bank protection. The shoreline was strengthened by huge built-in stone blocks and steel net that is thickly covered with plants. The findings showed the presence of G. vulgatissimus (N: 440), $O$. forcipatus (N: 223), O. cecilia (N: 10), G. flavipes (N: 3), P. pennipes (N: 3) and $C$. splendens ( $\mathrm{N}: 2$ ). The species of $O$. cecilia is on the Red List of Threatened Species in Ukraine and it is listed in the Bern Convention (Титар, 2009).The F3TL stretch was the most popular place of emergence of the dragonfly larvae which was surprising considering its disturbed, artificially reconstructed character (Table 1, Table 2).

Table 1. The composition of dragonfly assemblages based on the exuvial samples on the examined habitats ( $N$ : number of exuviae)

\begin{tabular}{|c|c|c|c|c|c|c|c|c|c|c|c|c|c|}
\hline \multirow[t]{2}{*}{$\begin{array}{l}\text { Sampling } \\
\text { site }\end{array}$} & \multirow[t]{2}{*}{$\begin{array}{l}\text { Coordinates } \\
\text { (UTM) }\end{array}$} & \multicolumn{2}{|c|}{ 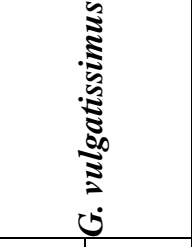 } & \multicolumn{2}{|c|}{ 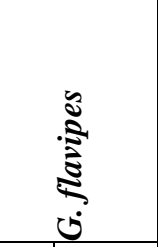 } & \multicolumn{2}{|c|}{ 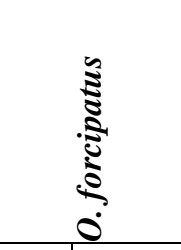 } & \multicolumn{2}{|c|}{ 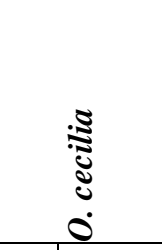 } & \multicolumn{2}{|c|}{ 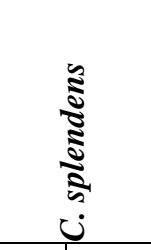 } & \multicolumn{2}{|c|}{ 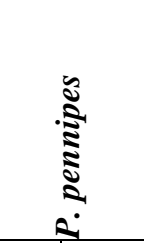 } \\
\hline & & $\mathbf{N}$ & $\%$ & $\mathbf{N}$ & $\%$ & $\mathbf{N}$ & $\%$ & $\mathbf{N}$ & $\%$ & $\mathbf{N}$ & $\%$ & $\mathbf{N}$ & $\%$ \\
\hline F1TL & $\begin{array}{l}34 \mathrm{U} 0637707 \\
5328548\end{array}$ & 33 & 50.00 & 0 & 0 & 30 & 45.45 & 3 & 4.55 & 0 & 0 & 0 & 0 \\
\hline F2TL & $\begin{array}{l}34 \mathrm{U} 0638005 \\
5328971\end{array}$ & 18 & 81.82 & 0 & 0 & 3 & 13.64 & 1 & 4.55 & 0 & 0 & 0 & 0 \\
\hline F3TL & $\begin{array}{l}34 \mathrm{U} 0638333 \\
5329270\end{array}$ & 224 & 68.92 & 3 & 0.92 & 89 & 27.38 & 5 & 1.54 & 1 & 0.31 & 3 & 0.92 \\
\hline F4TL & $\begin{array}{l}34 \mathrm{U} 0638966 \\
5328503\end{array}$ & 165 & 61.57 & 0 & 0 & 101 & 37.69 & 1 & 0.37 & 1 & 0.37 & 0 & 0 \\
\hline F1TB & $\begin{array}{l}34 \mathrm{U} 0639748 \\
5327518\end{array}$ & 48 & 48.48 & 14 & 14.14 & 25 & 25.25 & 12 & 12.12 & 0 & 0 & 0 & 0 \\
\hline F2TB & $\begin{array}{l}34 \mathrm{U} 0640224 \\
5326415\end{array}$ & 97 & 80.83 & 6 & 5.00 & 15 & 12.50 & 1 & 0.83 & 1 & 0.83 & 0 & 0 \\
\hline F1TH & $\begin{array}{l}\text { 34U } 0639600 \\
5328618\end{array}$ & 1 & 1.32 & 0 & 0 & 72 & 94.74 & 2 & 2.63 & 1 & 1.32 & 0 & 0 \\
\hline F2TH & $\begin{array}{l}34 \mathrm{U} 0639861 \\
5328351\end{array}$ & 143 & 47.67 & 0 & 0 & 142 & 47.33 & 13 & 4.33 & 2 & 0.67 & 0 & 0 \\
\hline F1NSZ & $\begin{array}{l}34 \mathrm{U} 0655369 \\
5334794\end{array}$ & 66 & 73.33 & 0 & 0 & 24 & 26.67 & 0 & 0 & 0 & 0 & 0 & 0 \\
\hline F2NSZ & $\begin{array}{l}34 \mathrm{U} 0655288 \\
5334678\end{array}$ & 210 & 65.42 & 0 & 0 & 110 & 34.27 & 0 & 0 & 1 & 0.31 & 0 & 0 \\
\hline F1H & $\begin{array}{l}34 \mathrm{U} 0669587 \\
5337028\end{array}$ & 31 & 88.57 & 0 & 0 & 4 & 11.43 & 0 & 0 & 0 & 0 & 0 & 0 \\
\hline F2H & $\begin{array}{l}34 \mathrm{U} 0669743 \\
5336511\end{array}$ & 17 & 22.67 & 0 & 0 & 58 & 77.33 & 0 & 0 & 0 & 0 & 0 & 0 \\
\hline F3H & $\begin{array}{l}\text { 34U } 0669993 \\
5335854\end{array}$ & 73 & 43.45 & 0 & 0 & 95 & 56.55 & 0 & 0 & 0 & 0 & 0 & 0 \\
\hline & otal & 1126 & \begin{tabular}{|l|l|}
57.30 \\
\end{tabular} & 23 & 1.17 & 768 & 39.08 & 38 & 1.93 & 7 & 0.36 & 3 & 0.15 \\
\hline
\end{tabular}


Table 2. The composition of dragonfly assemblages based on the exuvial samples examined in River Tisza sections belonging to settlements ( $N$ : number of exuviae)

\begin{tabular}{|c|c|c|c|c|c|c|c|c|c|c|c|c|}
\hline \multirow[t]{2}{*}{ Settlement } & \multicolumn{2}{|c|}{ 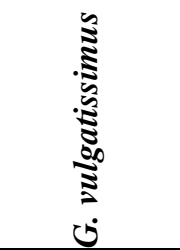 } & \multicolumn{2}{|c|}{ 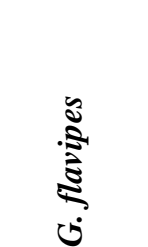 } & \multicolumn{2}{|c|}{ 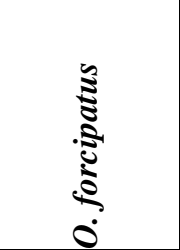 } & \multicolumn{2}{|c|}{ 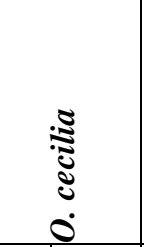 } & \multicolumn{2}{|c|}{ 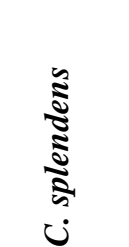 } & \multicolumn{2}{|c|}{ 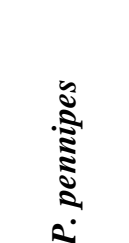 } \\
\hline & $\mathbf{N}$ & $\%$ & $\mathbf{N}$ & $\%$ & $\mathbf{N}$ & $\%$ & $\mathbf{N}$ & $\%$ & & $\%$ & $\mathbf{N}$ & $\%$ \\
\hline $\begin{array}{l}\text { Vilok } \\
\text { (Вилок, Tiszaújlak) }\end{array}$ & 440 & 71.54 & 3 & 0.49 & 223 & 36.26 & 10 & 1.63 & 2 & 0.33 & 3 & 0.49 \\
\hline $\begin{array}{l}\text { Tiszobikeny } \\
\text { (Tисабикень, Tiszabökény) }\end{array}$ & 145 & 66.21 & 20 & 9.13 & 40 & 18.26 & 13 & 5.94 & 1 & 0.46 & 0 & 0 \\
\hline $\begin{array}{l}\text { Nove Szelo } \\
\text { (Нове Село, Tiszaújhely) }\end{array}$ & 144 & 38.30 & 0 & 0 & 214 & 56.91 & 15 & 3.99 & 3 & 0.80 & 0 & 0 \\
\hline $\begin{array}{l}\text { Vinohragyiv } \\
\text { (Виноградів, Nagyszőlős) }\end{array}$ & 276 & 67.15 & 0 & 0 & 134 & 32.60 & 0 & 0 & 1 & 0.24 & 0 & 0 \\
\hline $\begin{array}{l}\text { Huszt } \\
\text { (Хуст, Huszt) }\end{array}$ & 121 & 43.53 & 0 & 0 & 157 & 56.47 & 0 & 0 & 0 & 0 & 0 & 0 \\
\hline
\end{tabular}

On the main channel of River Tisza at Tiszobikeny collections were carried out on two stretches F1TB and F2TB. The F1TB stretch had point bars and accompanied by the channel they were covered with sandy soil while the F2TB sampling site can be found on the side of a coastal defence dam, made up of stone blocks. The plant cover was sparse on both of the sampling sites. At the Tiszobikeny stretch the species of $G$. vulgatissimus $(\mathrm{N}: 145)$ appeared most frequently. O. forcipatus $(\mathrm{N}: 40)$, G. flavipes $(\mathrm{N}$ : 20), O. cecilia (N: 13) and C. splendens (N: 1) also could be found in the area. During the collections this was the place where G. flavipes appeared most often and in the greatest number (Table 1, Table 2).

At Nove Szelo on River Tisza a total number of 376 exuviae could be collected. $O$. forcipatus (N: 214) was the most frequent species on the two sampling sites. Significant assemblages could be found of G. vulgatissimus $(\mathrm{N}: 144), O$. cecilia $(\mathrm{N}: 15)$ and $C$. splendens (N: 3). Exuviae of G. flavipes could not be found at this sampling site; however their presence was confirmed in the earlier works of Kolozsvári and Dévai (2013) on the side channel of River Tisza at Nove Szelo. Cut banks were dominating on the F1TH and F2TH stretches. The bank material of the F1TH stretch was rough (coarse-grained) pebbled with stone blocks while the F2TH stretch was sandy and pebbly. At the foot of the cut banks the plant cover is sparse and mosaic-like.

Differences could be found in the number of exuviae on the apparently similar sampling sites. On the F1TH stretch the species of $O$. forcipatus $(\mathrm{N}: 72)$ were dominant, while on the $\mathrm{F} 2 \mathrm{TH}$ stretch the species of G. vulgatissimus $(\mathrm{N}: 143)$ and O. forcipatus $(\mathrm{N}: 142$ ) could be found almost equally in number (Table 1, Table 2).

In the Vinohragyiv section of River Tisza altogether 411 exuviae were collected from two sampling sites. The F1NSZ stretch has point bar, gradually deepening with pebbly bottom while on the F2NSZ stretch coastal defence was carried out earlier. At both sampling sites the river banks were covered with ligneous and bushy vegetation. Exuviae of G. vulgatissimus (N: 276), and O. forcipatus (N: 134) could be found on the main channel of River Tisza at Vinohragyiv (Table 1, Table 2). The presence of $O$. cecilia was revealed by the earlier collections of Kolozsvári and Dévai (2013). 
Exuviae collection was carried out on three stretches in the area of Huszt. At the F1H stretch point bars were observed, at the $\mathrm{F} 2 \mathrm{H}$ stretch protected banks and the $\mathrm{F} 3 \mathrm{H}$ stretch cut banks were found. In the Tisza section of Huszt, O. forcipatus (N: 157) and G. vulgatissimus ( $\mathrm{N}$ : 121) riverine dragonflies could be found, similarly to the results of Vinohragyiv (Table 1, Table 2).

Differences could be found in the occurrence of the species of the Gomphidae family. While in the section of River Tisza between Vilok and Tiszobikeny all the four identified species of riverine dragonflies were present, in the area of Vinohragyiv and Huszt, only G. vulgatissimus and $O$. forcipatus species could be detected. Our investigation showed, that in the river sections of Vilok, Tiszobikeny and Vinohragyiv the species of $G$. vulgatissimus were the most frequent while in the sections of Nove Szelo and Huszt the species of $O$. forcipatus were the most recurrent.

When choosing the place of emergence the types of river banks were preferred differently by the different species. Point bars [F1TL, F2TL, F4TL, F1TB, F1NSZ, $\mathrm{F} 1 \mathrm{H}]$ and artificially reconstructed protected banks [F3TL, F2TB, F2NSZ, F2H] were chosen mostly by the species of G. vulgatissimus. In the case of cut banks [F1TH, $\mathrm{F} 2 \mathrm{TH}, \mathrm{F} 3 \mathrm{H}]$ the species of $O$. forcipatus $(56.80 \%)$ was the most frequent (Table 3).

Table 3. The composition of dragonfly assemblages based on the exuvial samples on the examined types of river banks ( $N$ : number of exuviae)

\begin{tabular}{|c|c|c|c|c|c|c|c|c|c|c|c|c|}
\hline \multirow[t]{2}{*}{ Types of river banks } & \multicolumn{2}{|c|}{ 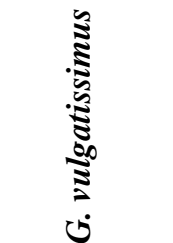 } & \multicolumn{2}{|c|}{ 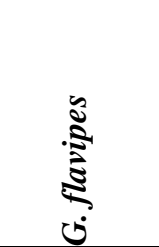 } & \multicolumn{2}{|c|}{ 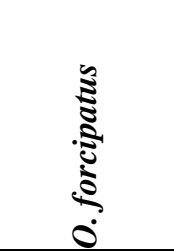 } & \multicolumn{2}{|c|}{ 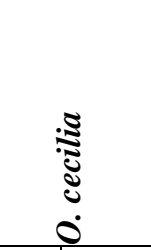 } & \multicolumn{2}{|c|}{ 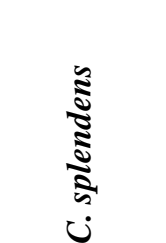 } & \multicolumn{2}{|c|}{ 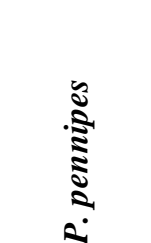 } \\
\hline & $\mathbf{N}$ & $\%$ & $\mathbf{N}$ & $\%$ & $\mathbf{N}$ & $\%$ & $\mathbf{N}$ & $\%$ & $\mathbf{N}$ & $\%$ & $\mathbf{N}$ & $\%$ \\
\hline Point bars & 361 & 62.24 & 14 & 2.41 & 187 & 32.24 & 17 & 2.93 & 1 & 0.17 & 0 & 0 \\
\hline Cutbanks & 217 & 39.89 & 0 & 0 & 309 & 56.80 & 15 & 2.76 & 3 & 0.55 & 0 & 0 \\
\hline Reconstructed banks & 548 & 65.16 & 9 & 1.07 & 272 & 32.34 & 6 & 0.71 & 3 & 0.36 & 3 & 0.36 \\
\hline
\end{tabular}

By cluster analysis (Ward's method) three clusters are separated that is confirmed by principal coordinate analysis based on Bray\&Curtis similarity (the two axes explain $76.84 \%$ of the variation). Examinations carried out by multivariate normality test (Mardia's test) show normal distribution of exuviae number. According to the canonical variate analysis the division of the 3 groups (Fig. 2) is rather strong (Wilks' lambda $=0.002, \mathrm{~F}=19.96, \mathrm{p}<0.001)$. Based on the result of SIMPER the exuviae of $G$. vulgatissimus $(72.67 \%$ ) are responsible for the division of the 3 groups to a large extent while the exuviae of $O$. forcipatus $(27.00 \%)$ are responsible to a smaller degree.

In compliance with the Mantel test the channel and riverbank characteristics show a significant correlation with the composition of dragonfly assemblages $(\mathrm{R}=0.309$, $\mathrm{p}=0.024)$. According to the canonical correspondence analysis (15 habitat characteristics) the exuviae data of G. vulgatissimus are connected with the extent of plant coverage (7), the rate of foliage closure (8) and the characteristics of riverbanks (14); the exuviae data of $O$. forcipatus are associated with water depth (2), channel deepening tendency (3), type of plant coverage on the river bank (6) and water temperature (11); the exuviae data of $G$. flavipes and $O$. cecilia are related to the mosaic-like bottom of the channel (4), the intensity of water flow near the river banks 
(9), the rate of foliage closure (8), the rate of plant coverage of the riverbank (7) and type of the river bank (12) (Fig. 3).

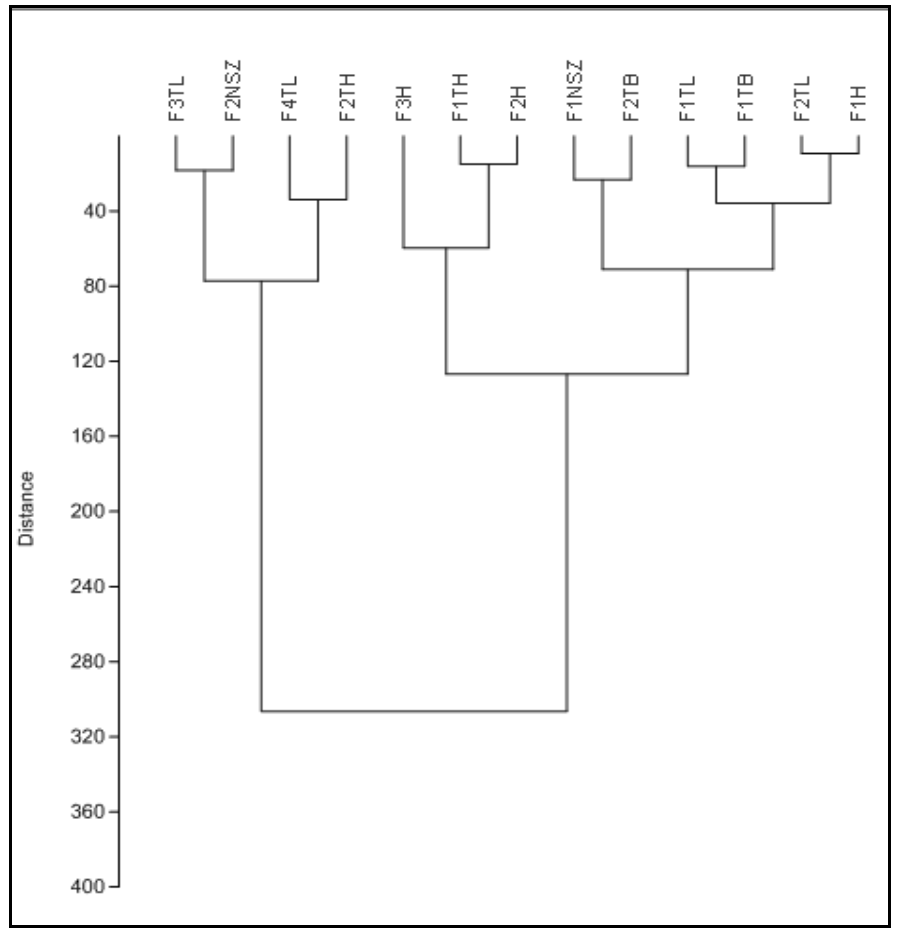

Figure 2. By cluster analysis (Ward's method) three clusters are separated based on dragonfly assemblages and sampling sites

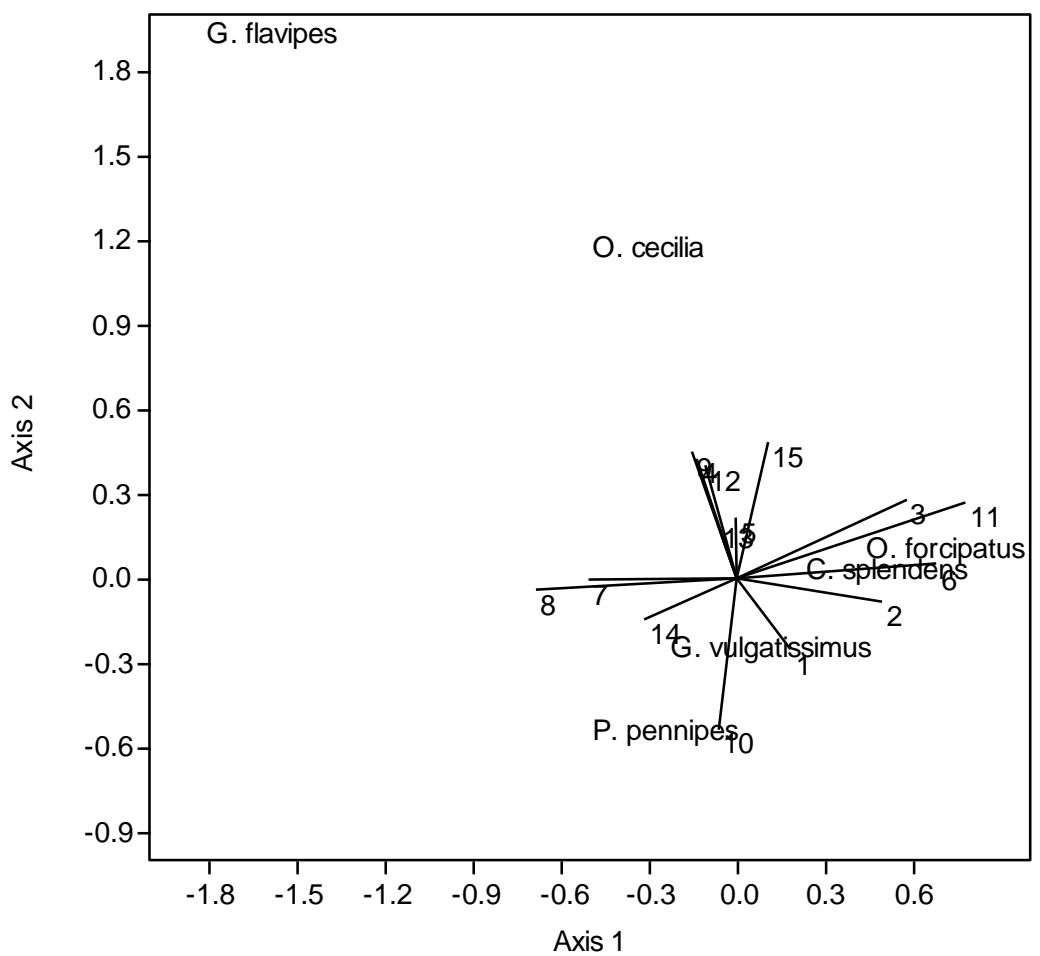

Figure 3. Result of canonical correspondance analysis based on species and 15 habitat characteristics 


\section{Discussion}

The aim of our work was to get an overview of the dragonfly fauna of River Tisza in the section between Vilok and Huszt and to gather information about the characteristics of their occurrence and quantity based on the data of exuviae collections (Fig. 1). If river regulation extends to the given section of the river, there will not be any opportunity for studying these natural habitats along the River Tisza. Our samplings were carried out on 13 main channel sites on 30 metres long stretches in the area of Vilok (Вилок, Tiszaújlak), Nove Szelo (Нове Село, Tiszaújhely), Tiszobikeny (Тисабікень, Tiszabökény), Vinohragyiv (Виноградів, Nagyszőlős) and Huszt (Хуст, Huszt). Based on our exuvial data altogether 6 dragonfly species could be identified [Gomphus vulgatissimus, Gomphus flavipes, Onychogomphus forcipatus, Ophiogomphus cecilia, Calopteryx splendens, Platycnemis pennipes].

The species of $G$. vulgatissimus and $O$. forcipatus could be found at all of the 13 sampling sites. More than half of our exuviae samplings belonged to the species of $G$. vulgatissimus $(57.3 \%)$, but significant assemblages of $O$. forcipatus $(39.08 \%)$ could be found as well. In case of $G$. vulgatissimus most of the exuviae were collected on the stretches of Vilok F3TL (N: 224) and Vinohragyiv F2NSZ (N: 210), the main channel of River Tisza. River bank protection was carried out in both cases of the sampling sites. The exuviae of $O$. cecilia $(1.93 \%)$ and $G$. flavipes $(1.17 \%)$ were scarcely found, but seemed to be present in the examined section of the river. O. cecilia could be found on the stretches of Vilok, Tiszobikeny and Nove Szelo and exuviae of G. flavipes could be gathered at the sampling sites of Vilok and Tiszobikeny. Two specimens of the Zygoptera suborder were isolated: C. splendens $(0.36 \%)$ and $P$. pennipes $(0.15 \%)$. The mosaic-like composition and occurrence of the dragonfly fauna was general (Table 1 , Table 2). The background of this phenomenon is not exactly known, but presumably there are connections between the dynamically changing channel, the river bank structures and the abundance of the habitats in the area.

According to our investigations significant correlation can be found between the occurrence of the dragonfly assemblages and the characteristics of natural habitats in the examined sections. The occurrence of G. vulgatissimus exuviae is connected with the rate of plant coverage (7), the rate of foliage closure (8) and the characteristics of the river bank (14); the exuviae of $O$. forcipatus are associated with the water depth (2), the deepening tendency of the channel (3), the type of plant coverage on the river bank (6) and water temperature (11). The assemblages of G. flavipes and O. cecilia exuviae are related to the mosaic-like nature of the channel (4), the intensity of water flow near the river banks (9), the rate of foliage closure (8) and the rate of plant coverage (7) (Fig. 3). The collection of exuviae is hindered by their considerable fragility (Bennett and Mill, 1993; Corbet and Hoess, 1998; Corbet, 1999).

As similar investigations were not conducted on our collecting area, the results of our research cannot be compared to previous data of the Upper-Tisza area. It has already been proved that the composition of aquatic macroinvertebrate communities is largely influenced by the abiotic and biotic factors of the habitat. (Corbet, 1983; Gibbons and Pain, 1992; Brookes, 1994; Beisel et al., 1998; Brunke et al., 2001; Angelier, 2003; Ward and Mill, 2005). This has been confirmed by several detailed odonatological surveys in respect of dragonflies as well (Müller, 1995; Lohr, 2010), however the variegation of the habitat factors and the adaptability of dragonflies, make it more difficult to learn the habitat factors on the level of species. It is often observable that some specimens belonging to the same dragonfly species show different sediment and 
emergence substrate preference (Suhling, 1996; Farkas et al., 2011). The characteristics of the river bank and channel structure, as well as the river current factors greatly influence the ecological peculiarities of a given habitat (sediment composition, oxygen level, temperature, etc.), and thus the composition of the dragonfly fauna (Lutz, 1974; Baker, 1980; Spence et al., 1980; Baker and Feltmate, 1989; Corkum and Hanes, 1992; Wood, 1998; Müller, 2002; Corbet, 2003). On the fast-moving river sections the deepest section is in the streamline, there the habitat conditions are the least favorable for the dragonfly larvae. Despite of the fact, that dragonfly larvae usually prefer the slower watercourses and more protected habitats, it is also observable in case of the riverine dargonflies (Gomphidae) that the species of $O$. forcipatus and O. cecilia tolerate the fast-moving river sections better than the species of G. vulgatissimus and G. flavipes (Corbet, 1983; Suhling, 1996; Suhling and Müller, 1996; Gerken and Sternberg, 1999; Burcher and Smock, 2002; Müller, 2002). Müller's (2002, 2004) samplings carried out on the Odera also showed much larger larval presence on the river bank area than in the streamline in case of the Gomphidae species. Vegetation is also a key component in the stabilization of the river banks (Hickin, 1984; Davis and Gregory, 1994), furthermore it influences the emergence strategy of the riverine dragonflies, the selection of the place of emergence and the extent of larvae departure from water (Corbet, 1983, 1999; Farkas et al., 2011). According to our experience, scientific literature is not always unified in the peculiarities of dragonfly larvae habitat selection as well as in the selection of their place of emergence (Trottier, 1973; Mathavan and Pandian, 1977; Geissen, 2000; Jakab, 2006; Hardersen, 2008).

The typically changing channel and river bank structure of the upper Tisza section hinders the tracing of dragonfly assemblages and the recognition of quantitative changes. In case of species of the Gomphidae family there is a great diversity because of the continuously changing river channel. In the area of Vilok and Tiszobikeny all the four species of riverine dragonflies were found but in the area of Huszt, only the species of G. vulgatissimus and O. forcipatus were present. The section of the River Tisza between Vilok and Huszt is mostly untouched and an anastomosing riverine main-sidedead channels system is preserved. The given section is unique along the whole channel of the River Tisza. From the point of biodiversity research the significance of the so naturally preserved habitats is increasing.

Acknowledgements. This research was realized in the frames of TÁMOP 4.2.4.A/2-11-1-2012-0001 „National Excellence Program - Elaborating and operating an inland student and researcher personal support system". The project was subsidized by the European Union and co-financed by the European Social Fund. The authors would like to thank Enikő Nagy-Kolozsvári and László Berzi-Nagy for the linguistic corrections of the manuscript.

\section{REFERENCES}

[1] Amoros, C. (2001): The Concept of Habitat Diversity Between and Within Ecosystems Applied to River Side-Arm Restoration. - Environmental Management 28 (6): 805- 817.

[2] Angelier, E. (2003): Ecology of Streams and Rivers. - Science Publishers Inc., Enfield.

[3] Askew, R.R. (2004): The dragonflies of Europe (revised edition). - Harley Books, Colchester.

[4] Baker, R.L. (1980): Use of space in relation to feeding areas by zygopteran nymphs in captivity. - Can. J. Zool. 58: 1060-1065. 
[5] Baker, R.L., Feltmate, B.W. (1989): Depth selection by larval Ischnura verticalis (Odonata: Coenagrionidae): effects of temperature and food. - Freshwater Biology 22: 169-175.

[6] Beisel, J.N., Usseglio-Polatera, P., Thomas, S., Moreteau, J.C. (1998): Stream community structure in relation to spatial variation: the influence of mesohabitat characteristics. Hydrobiologia 389: 73-88.

[7] Bellmann, H. (2007): Der Kosmos-Libellenführer. Die Arten Mitteleuropas sicher bestimmen. - Franckh-Kosmos Verlags-GmbH \& Co. KG, Stuttgart.

[8] Bennett, S., Mill, P.J. (1993): Larval development and emergence in Pyrrhosoma nymphula (Sulzer) (Zygoptera: Coenagrionidae). - Odonatologica 22: 133-145.

[9] Bereczki, Cs., Szivák, I., Móra, A., Csabai, Z. (2012): Variation of aquatic insect assemblages among seasons and microhabitats in Hungarian second-order streams. Aquatic Insects 34(1): 103-112.

[10] Bravard, J.P., Amoros, C., Pautou, G. (1986): Impact of civil engineering works on the successions of communities in a fluvial system. - Oikos 47 (1): 92-111.

[11] Brookes, A. (1994): River Channel Change. - In: Calow P., Petts, G.E. (eds.) The Rivers Handbook, Vol. 1., p. 55-75.

[12] Brunke, M., Hoffmann, A., Pusch, M. (2001): Use of mesohabitat-specific relationships between flow velocity and river discharge to assess invertebrate minimum flow requirements. - Regul. Rivers: Res. Mgmt. 17: 667-676.

[13] Burcher, C.L., Smock, L.A. (2002): Habitat distribution, dietary composition and life history characteristics of odonate nymphs in a blackwater coastal plain stream. American Midland Naturalist 148/1: 75-89.

[14] Carling, P.A. (1994): In-stream Hydraulics and Sediment Transport. - In The Rivers Handbook, Vol. 1, Chapter 6, Calow, P. and Petts, G.E. (eds.), p. 101-125.

[15] Chovanec, A, Waringer, J. (2001): Ecological integrity of river-floodplain systemsassessment by dragonfly surveys (Insecta: Odonata). - Regul. Rivers: Res. Mgmt. 17: 493-507.

[16] Church, M. (1994): Channel Morphology and typology. - In: Calow P., Petts, G.E. (eds.) The Rivers Handbook, Vol. 1., p. 126-143.

[17] Corbet, P.S. (1983): A biology of dragonflies. Facsimile reprint. - E.W. Classey Ltd., Faringdon.

[18] Corbet, P.S. (1999): Dragonflies: behaviour and ecology of Odonata. - Harley Books, Colchester, XXXIII + 829 pp., 17 plates.

[19] Corbet, P.S. (2003): A positive correlation between photoperiod and development rate in summer species of Odonata could help to make emergence date appropriate to latitude: a testable hypothesis. - Journal of the Entomological Society of British Columbia 100: 317.

[20] Corbet, P.S., Hoess, R. (1998): Sex ratio of Odonata at emergence. - International Journal of Odonatology 1: 99-118.

[21] Corkum, L.D., Hanes, E.C. (1992): Effects of temperature and photoperiod on larval size and survivorship of a burrowing mayfly (Ephemeroptera, Ephemeridae). - Can. J. Zool. 70: 256-263.

[22] D'Amico, F., Darblade, S., Avignon, S., Blanc-Manel, S., Ormerod, S.J. (2004): Odonates as indicators of shallow lake restoration by liming: comparing adult and larval responses. - Restoration Ecology 12: 439-446.

[23] Davis, R.J., Gregory, K.J. (1994): A new distinct mechanism of river bank erosion in a forested catchment. - Journal of Hydrology 157: 1-11.

[24] Farkas, A., Jakab, T., Dévai, Gy. (2011): A folyami szitakötők (Odonata: Gomphidae) lárváinak kirepülést megelőző viselkedése a Tisza vízrendszerén exuviumfelmérések alapján (Emergence behaviour of riverine dragonfly (Odonata: Gomphidae) larvae along the Tisza river system based on exuviae surveys). - Acta biol. debrecina, Suppl. oecol. hung. 26: 53-66. 
[25] Farkas, A., Jakab, T., Tóth, A., Kalmár, F.A., Dévai, Gy. (2012): Emergence patterns of riverine dragonflies (Odonata: Gomphidae) in Hungary: variations between habitats and years. - Aquatic Insects 34 (S1): 77-89.

[26] Fudakowski, J. (1935): Przyczynek do znajomości fauny Czarnogory. Ważki (Odonata) (Contribuants á la faune du Massif de Czarnohora. Libellule). - Instytut badawczy lasów Państwowych. Serja A, Nr. 8, Warszawa, 38-42.

[27] Geissen, H.P. (2000): Gomphidae vom südlichen Mittelrhein (Odonata). - Libellula 19: $157-174$.

[28] Gerken, B., Sternberg, K. (1999): Die Exuvien europäischer Libellen (Insecta, Odonata). - Arnika \& Eisvogel, Höxter \& Jena.

[29] Gibbons, D.W., Pain, D. (1992): The influence of river flow rate on the breeding behaviour of Calopteryx damselflies. - Journal of Animal Ecology 61: 283-289.

[30] Giugliano, L., Hardersen, S., Santini, G. (2012): Odonata communities in retrodunal ponds: a comparison of sampling methods. - International Journal of Odonatology 15: $13-23$.

[31] Gönczy, S., Molnár, J. (2004): A tiszai vízjárás változások valószínủ okai (The possible reasons of water regime change of River Tisza). - Müszaki Szemle 25: 10-16.

[32] Hammer, O., Harper, D.A.T., Ryan, P.D. (2001), 'PAST: Paleontological statistics software package for education and data analysis', Palaeontologia Electronica, 4(1), 1-9, http://palaeo-electronica.org/2001_1/past/issue1_01.htm.

[33] Hardersen, S. (2008): Dragonfly (Odonata) communities at three lotic sites with different hydrological characteristics. - Italian Journal of Zoology 75: 271-283.

[34] Hickin, E.J. (1984): Vegetation and river channel dynamics. - Canadian Geographer XXVIII/2: 111-126.

[35] Hoffman, D.F., Gabet, E.J. (2007): Effects of sediment pulses on channel morphology in a gravel-bed river. - Geological Society of America Bulletin 119 (1-2): 116-125.

[36] Holuša, O. (2009): New records of Cordulegaster bidentata and Somatochlora alpestris in the Ukrainian Carpathians (Odonata: Cordulegastridae, Corduliidae). - Libellula 28 (3/4): 191-201.

[37] Hrabár, S. (1905): Ung és Ugocsa megye szitakötő faunája (The dragonfly fauna of Ung and Ugocsa counties). - Rovartani Lapok XII: 101-103.

[38] Jakab, T., Dévai, Gy. (2008): A folyami szitakötők (Odonata: Gomphidae) előfordulása Magyarországon a lárva- és exuviumadatok alapján (The occurrence of the riverine dragonfly-species (Odonata: Gomphidae) in Hungary according to data of larvae and exuviae). - Acta biol. debrecina, Suppl. oecol. hung. 18: 53-65.

[39] Kohaut, R. (1896): A magyarországi szitakötőfélék természetrajza (Libellulidae Auct., Odonata Fabr.) (The natural history of dragonflies in Hungary). - K. M. Természettudományi Társulat, Budapest.

[40] Kolozsvári, I., Dévai, Gy. (2013): Dragonfly fauna of the main, side and dead channels of River Tisza in Ukrainian section. - 32. Jahrestagung der Gesellschaft deutschsprachiger Odonatologen (GdO) e. V., Fulda, p. 56-57.

[41] Kolozsvári, I., Illár, L. (2009): A Tisza tiszaújlaki szakaszán élő szitakötőfajok faunisztikai felmérése (Faunistic survey of the dragonfly fauna of the River Tisza section above Tiszaújlak). - Acta beregsasiensis VIII/1: 231-240.

[42] Kovács, T., Godunko, R.J. (2008): Faunistical records of larvae of Ephemeroptera, Odonata and Plecoptera from the Zakarpats'ka Region, Ukraine. - Folia hist.-nat. Mus. matr. 32: 87-91.

[43] Kovács, T., Godunko, R.J., Juhász, P., Kiss, B., Müller, Z. (2008): Quantitative records of larvae of Ephemeroptera, Odonata and Plecoptera from the Zakarpats'ka Region, Ukraine (2004, 2006). - Folia hist.-nat. Mus. matr. 32: 135-147.

[44] Large, A.R.G., Petts, G.E. (1994): Rehabilitation of River Margins. - In The Rivers Handbook, Vol. 2, Chapter 6, Calow, P. and Petts, G.E. (eds.), p. 401-418. 
[45] Lászlóffy, W. (1949): A folyómedrek vándorlása. A vicksburgi laboratórium kismintatanulmányai Friedkin J.F. tanulmánya nyomán. - Vízügyi Közlöny 31/1-2: 98-115. (The wandering of river beds. Small-scale river studies of Vicksburg laboratory based on the study of Friedkin J.F.)

[46] Lohr, M. (2010): Libellen zweier europäischer Flusslandschaften. Besiedlungsdynamik und Habitatnutzung von Libellengemeinschaften am Unteren Allier (Frankreich) und an der Oberweser (Deutschland). - Arbeiten aus dem Institut für Landschaftsökologie, Nr. 17, Münster, IV +vi $+183 \mathrm{pp}$.

[47] Lutz, P.E. (1974): Effects of temperature and photoperiod on larval development in Tetragoneuria cynosura (Odonata: Libellulidae). - Ecology 55/2: 370-377.

[48] Martynov, A.V., Martynov, V.V. (2010): Distribution of Cordulegaster bidentata Selys, 1843 (Odonata, Cordulegasteridae) in Ukraine. - Eurasian Entomological Journal 9/2: 303-307.

[49] Mathavan, S., Pandian, T.J. (1977): Patterns of emergence, import of egg energy and energy export via emerging dragonfly populations in a tropical pond. -Hydrobiologia 54: 257-272.

[50] Mauersberger, R. (1994): Zur wirklichen Verbreitung von Orthetrum coerulescens (Fabricius) und O. ramburi (Selys) $=$ O. anceps (Schneider) in Europa und die Konsequenzen für deren taxonomischen Rang (Odonata, Libellulidae). - Deutsche entomologische Zeitschrift, Neue Folge 41: 235-256.

[51] Molnár, J., Molnár, D.I. (2005): Kárpátalja népessége és magyarsága a népszámlálási és népmozgalmi adatok tükrében (Study on the population and Hungarians of Transcarpathia based on the census and demographical data). - Kárpátaljai Magyar Pedagógusszövetség, Beregszász.

[52] Montgomery, D.R., Buffington, J.M. (1997): Channel-reach morphology in mountain drainage basins. - Geological Society of America Bulletin 109 (5): 596-611.

[53] Müller, O. (1995): Ökologische Untersuchungen an Gomphiden (Odonata: Gomphidae) unter besonderer Berücksichtigung ihrer Larvenstadien. Dissertation. - Cuvillier Verlag, Göttingen, VI + $235 \mathrm{pp}$.

[54] Müller, O. (2002): Die Habitate von Libellenlarven in der Oder (Insecta, Odonata). Naturschutz und Landschaftspflege in Brandenburg 11 (3): 205-212.

[55] Müller, O. (2004): Steinschüttungen von Buhnen als Larval-Lebensraum für Ophiogomphus cecilia (Odonata: Gomphidae). - Libellula 23/1-2: 45-51.

[56] Németh, E. (1954): Hidrológia és hidrometria (Hydrology and hydrometry). Tankönyvkiadó, Budapest.

[57] Noss, R.F. (1990): Indicators for Monitoring Biodiversity: A Hierarchical Approach. Conservation Biology Volume 4: 355-364.

[58] Raebel, E.M., Merckx, T., Riordan, P., Macdonald, D.W., Thompson, D.J. (2010): The dragonfly delusion: Why it is essential to sample exuviae to avoid biased surveys. Journal of Insect Conservation 14: 523-533.

[59] Richard, G.A., Pierre, T., Julien, Y., Baird, D.C. (2005): Statistical analysis of lateral migration of the Rio Grande, New Mexico. - Geomorphology 71: 139-155.

[60] Robert, A. (2003): River Processes. An Introduction to Fluvial Dynamics. - Arnold, London.

[61] Robert, A. (2011): Flow resistance in alluvial channels. - Progress in Physical Geography 35 (6): 765-781.

[62] Schindler, M., Fesl, C., Chovanec, A. (2003): Dragonfly associations (Insecta: Odonata) in relation to habitat variables: a multivariate approach. - Hydrobiologia 497: 169-180.

[63] Spence, J.R., Spence, D.H., Scudder, G.G.E. (1980): Submergence behavior in Gerris: Underwater basking. - American Midland Naturalist 103/2: 385-391.

[64] Suhling, F. (1996): Interspecific competition and habitat selection by the riverine dragonfly Onychogomphus uncatus. - Freshwater Biology 35: 209-217. 
[65] Suhling, F. - Müller, O. (1996): Die Flussjungfern Europas (Gomphidae). In: Die Neue Brehm-Bücherei 628. - Westarp \& Spektrum, Magdeburg, Heidelberg, 237 pp.

[66] Trottier, R. (1973): Influence of temperature and humidity on the emergence behaviour of Anax junius (Odonata: Aeshnidae). - Canadian Entomologist 105: 975-984.

[67] Vizslán, T., Huber, A. (2001): Odonate records from sub-Carpathia, southwestern Ukraine. - Notul. odonatol. 5/8: 103-105.

[68] Ward, L., Mill, P.J. (2005): Habitat factors influencing the presence of adult Calopteryx splendens (Odonata: Zygoptera). - Eur. J. Entomol. 102: 47-51.

[69] Ward, J.V., Tockner, K., Schiemer, F. (1999): Biodiversity of floodplain river ecosystems: ecotones and connectivity. - Regul. Rivers: Res. Mgmt. 15: 125 - 139.

[70] Ward, J.V., Tockner, K., Arscott, D.B., Clare, C. (2002): Riverine landscape diversity. Freshwater Biology 47, 517-539.

[71] Wood, P. (1998): Reach-scale mesohabitat variations in a small chalk stream under low flow conditions. In: Bretschko, G., Helešic, J. (edit.): Advances in river bottom ecology. Backhuys Publishers, Leiden, p. 31-38.

[72] Добей, В., Бондарчук, С. (1998): Фенологія рівнокрилих бабок (Odonata, Zygoptera) в умовах Закарпатської низовини (The fenology of the dragonflies (Odonata, Zygoptera) on the Transcarpathian lowland). - Науковий вісник Ужгородського Державного Університету, Серія Біологія 5: 137.

[73] Павлюк, Р.С. (1990): Стрекозы западных областей Украины (The dragonflies of the western districts of Ukraine). - Latvijas Entomologs 33: 37-80.

[74] Рязанова, Г.И. (2007): Репродуктивная тактика самцов Lestes sponsa (Hansemann) (Odonata, Zygoptera): индивидуальный репродуктивный успех или успех популяции (Reproduction tactics in the males of Lestes Sponsa (Hansemann) (Odonata, Zygoptera): individual reproduction success or success of the population). In: В.Б. Голуб (red.): Проблемы водной энтомологии России и сопредельных стран. - Издательскополиграфический центр Воронежского государственного университета, р. 287-292.)

[75] Титар, В.М. (2009): Офіогомфус цецилія (Ophiogomphus cecilia). In: Акімова, I.A. (red.): Червона книга України. Тваринний світ. - Глобалконсалтинг, Київ. 